ÉGYPTE

monde arabe

\section{Égypte/Monde arabe}

19 | 2019

Les zabbâlîn, un objet surétudié ?

\title{
Waste-recycling as a livelihood in the informal sector. The example of refuse collectors in Cairo
}

Le recyclage des déchets comme moyen de subsistance. L'exemple des éboueurs au Caire

\section{Günter Meyer}

\section{(2) OpenEdition}

\section{Journals}

Electronic version

URL: https://journals.openedition.org/ema/4576

DOI: 10.4000/ema.4576

ISSN: 2090-7273

Publisher

CEDEJ - Centre d'études et de documentation économiques juridiques et sociales

Printed version

Date of publication: 1 January 2019

Number of pages: 61-76

ISBN: 9782900956052

ISSN: $1110-5097$

Electronic reference

Günter Meyer, "Waste-recycling as a livelihood in the informal sector. The example of refuse collectors in Cairo", Égypte/Monde arabe [Online], 19 | 2019, Online since 01 January 2021, connection on 07 July 2022. URL: http://journals.openedition.org/ema/4576 ; DOI: https://doi.org/10.4000/ema.4576

All rights reserved 


\section{WASTE-REGYCLING AS A LIVELIHOOD IN \\ THE INFORMAL SECTOR. THE EXAMPLE \\ OF REFUSE COLLECTORS IN CAIRO}

Cet article est une réédition, avec l'aimable autorisation de son auteur, d'un article paru en 1987 dans le numéro 30 de la revue Applied Geography and Development.

Mountains of refuse on the outskirts of Lima, Lagos, Calcutta or Manila, with ragged children, youths, men and women rummaging through them for usable materials - this is a picture which probably almost everyone has come across in different variations again and again in magazines, books and films.

Like hardly any other picture, this one in particular seems to be especially well-suited to presenting visually and vividly the misery of the people on the outskirts of the metropolises in the Third World. In numerous publications on the informal sector also, which are focussed upon the survival economies of the urban poor in the developing countries (cf. for a summary of the situation Herrle 1983 and Elwert et al. 1983), a reference to the refuse collectors is rarely lacking. The people who earn their living by collecting, sorting and utilizing waste materials do work whose characteristics seem to conform in an ideal way to the criteria cited in numerous studies of the International Labour Organization (ILO) on the definition of activities of the informal sector. According to the latter, the small enterprises which operate in that economic sector are characterized particularly by the fact that they offer a livelihood to unskilled migrants from the rural areas and members of the lower urban social groups: 
- are usually family-owned and use mostly own family-labour;

- have recourse primarily to domestic raw materials or to waste, and use labour-intensive - but not necessarily "traditional" - technology;

- cannot satisfy their capital requirements on the official credit market, but have to have recourse to private lenders and

- frequently do not conform to the regulations, or operate illegally (cf. e. g. Sethuraman 1976 and 1981).

The realities which can be concealed behind this blanket definition of the informal sector will be examined, using as an example the more than 20,000 people who earn their living by using waste materials from the households of the middle and upper classes in Cairo. Most of them live under barely tolerable conditions in six refuse dump-settlements on the outskirts of the Egyptian metropolis, which has grown to its present population of more than 12 million inhabitants. The following exposition ${ }^{1}$ is focussed upon the social and economic situation of these population groups.

\section{DEVELOPMENT AND STRUCTURE OF THE SYSTEM OF HOUSEHOLD WASTE UTILIZATION IN CAIRO}

In order to understand how the present system of waste recycling in Cairo has evolved, one must first go back at least to the 1880's ${ }^{2}$. At that time the first migrants from the oasis depression of Dachla, in the western desert of Egypt, had come to Cairo and had begun to work as refuse collectors (Meyer 1980: 46). Their income was composed of the fees which they received from the households for carting the refuse away, and from the proceeds of their sale of the

1 The results presented here are based upon studies dating from 1978 and upon mappings and a series of large-scale interview surveys in the refuse settlements, carried out by the author in the autumn of 1985 and spring of 1986. The Deutsche Forschungsgemeinschaft (German Research Foundation), with a travel-grant, kindly supported the latter two research-stays in Cairo. The author would also like to thank Prof. Dr. Nabeel Embabi and Dr. Mohammed El-Deeb, Department of Geography at the Ain Shams University in Cairo, for their support.

2 Charts on guilds exist from the 16th and 17 th centuries, in which there is mention also of refuse collectors (cf. Baer 1964: 35 and 37); but since the forefathers of the present-day refuse collectors did not begin their work until towards the end of the 19th century, when the guilds had already been dissolved, no guild organizations exist here any longer. The refuse contractors' association has some quite guild-like elements in it; but it did not evolve until some decades later. 
unsorted refuse for fuel for the public baths of Cairo ${ }^{3}$. But after more and more baths started using fuel oil for heating the water from the '20s onwards, and the income from the sale of the refuse fell in consequence, the wahis - i.e. "the people from the oases" - were offered the alternative of selling domestic waste as feed for the pigs of Coptic immigrants who had settled on the outskirts of Cairo. The foundation stone was thus laid for a development which has resulted since the second half of the ' 30 s in the wahis escaping completely from the active collecting of refuse. They handed over the laborious, dirty work only too willingly - in return for payment - to the poor Coptic newcomers from Upper Egypt, who were prepared to do any kind of work which would ensure their economic survival in the metropolis. On the other hand, the wahis in no way gave up collecting the respective fees for waste removal from the households - i.e. collecting money for a service which they did not provide themselves, but was provided by the actual refuse collectors, the zabbaleen (Arab., singular form zabbal).

Such a system could be maintained only by forming a publicly-registered, Mafia-like association of refuse contractors. Membership of this association is reserved only for persons born in one of five villages of the Dachla oasis, or originating from there. The main tasks of the association headed by an elected board of directors consist, on the one hand, in acting as official representation of interests in relation to public agencies and, on the other, ensuring that no outsiders can gain access to the lucrative living from fees for refuse removal. Any competitors are excluded by every available means - by force, if necessary. Nevertheless, the refuse contractors could not prevent another, second group from participating in this lucrative business and creaming off part of the profits namely, the house-owners.

The system of refuse removal thus functions as follows (fig. 1): If a new residential building is erected anywhere, the house-owner offers the association of refuse contractors, for sale, the right to collect refuse. The price for this used to be determined in an auction, on the basis not only of the quality of the waste to be expected, but especially upon the estimated fees for removal of the refuse.

These fees are graded according to the lessee's income or ability to pay and range from 0.25 to $2 \mathrm{fE}$ monthly per dwelling ( $1 \mathrm{fE}$ is equivalent to about 1 US-Dollar). Sums amounting to several thousand $\mathrm{E} E$ were already being offered at the end of the ' $70 \mathrm{~s}$ for the right to collect refuse from larger apartment blocks in upper-class residential districts. In order to reduce competition tending to drive up prices as a result of excessive overbidding of one another, the contractors finally agreed to abolish the auction system. The purchaser of new refuse removal-rights is at present decided in negotiations between those contractors who already have rights in the adjoining areas, on the guiding

3 There is a detailed description of the use of refuse as fuel in the public baths in a report by the Sanitary Commissioners of Cairo, dating from 1909 (p. 1782). 


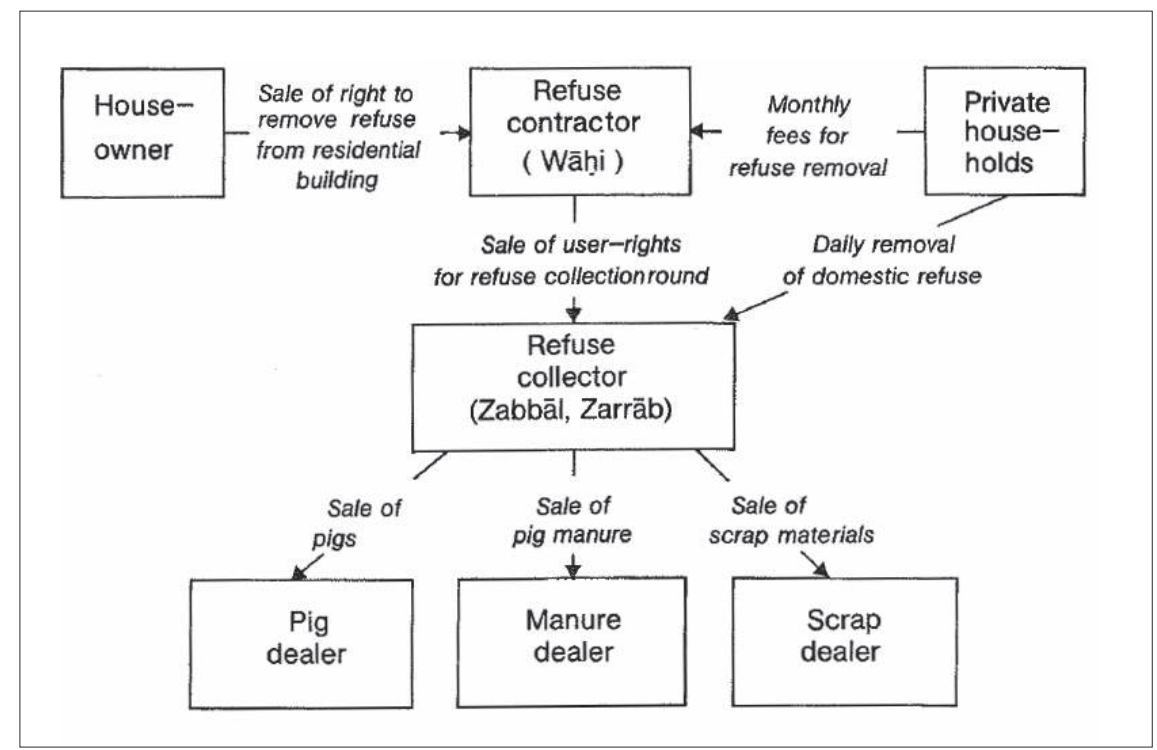

Figure 1: The system of recycling household refuse in Cairo

principle of area boundary-adjustment of the refuse contractors. Once acquired, the right of refuse removal from specified buildings is heritable. It can also be sold to other contractors or be let, and ceases only when the building concerned is demolished.

The contractor assigns the right to utilize the refuse to the zabbaleen, against payment of a cost price, the sum paid varying, of course, according to the expected quality of the refuse - usually being between 100 and $500 £ \mathrm{E}$ - for a route which will fill the donkey cart each day, and a varying number of buildings containing up to 250 dwellings. At the beginning of the '80s, prices of as much as $1000 £ \mathrm{E}$ had to be paid for a route in upper-class residential areas.

In addition, the zabbaleen used to have to pay a monthly fee of between 1 and $10 \mathrm{fE}$ per route to the contractor concerned. Owing to the rising costs of living and falling sales proceeds for scrap materials, the first zabbaleen were able to release themselves from this obligation already in the mid-70s, whereas most of them did not stop their payments until the beginning of the '80s. Only in isolated cases - large refuse-suppliers such as hospitals or hotels, in particular - do the wahis still receive their monthly commission even today.

The contractors offset the loss of income by increasing the fees which they collect each month from the households for carting refuse away. This brings some of the wahis who control five or six routes monthly incomes of more than $1000 \mathrm{EE}$ - a sum far higher than the annual income of an ordinary civil servant - which are often invested in real estate. It has not been necessary for these contractors for a long time to collect the refuse removal-fees themselves, of course. Young boys from amongst their poorer relatives are frequently employed 
for this. On the other hand, some of the wahis today have shopkeeper, owner of a supermarket, lawyer, doctor or even university professor as their main occupation. These men, who are either still living in their traditional immigration-area - the urban district Bab el-Bahr in the north-west of the old town - or have in the meantime moved away to the modern middle-class or upper-class residential areas, find being assigned to the informal sector very difficult. In the case of the zabbaleens, however, the picture is quite different.

\section{ORIGIN OF THE REFUSE COLLECTORS}

In a series of random-sample surveys during which the author interviewed one in ten owners of the 1,558 refuse collection units in the six refuse settlements of Cairo (fig. 2), it was found that the great majority of the zabbaleen (95\%) came there from the rural areas of Egypt. One sole exception is the inhabitants of the refuse settlement of Batn el-Bakr in the south of the metropolis. The zabbaleen-families there originally came from Old Cairo (Misr el-Qadima) and have been mostly working as refuse collectors for several generations already i.e. in most cases since the end of the 19th century.

The other zabbaleen-families come mostly (62\%) from the Upper Egyptian province of Assiut, and here particularly from the rural district of El-Badari, which is one of the Egyptian areas with very low per-capita income and high unemployment. The settlement Deir Tasa there is most frequently mentioned by the zabbaleen as their place of origin. One in three of the male heads of refuse collector-households was born there.

We have here - as we already had earlier in the case of the wahis - an example of "chain migration", which is typical of many migration processes all over the Third World. After the first immigrants from Deir Tasa had settled on the outskirts of Cairo as refuse collectors in the second half of the '30s, they first brought the members of their family and relatives there; then followed acquaintances from neighbouring villages. They settled near their respective predecessors and set themselves up - usually with the assistance of the latter likewise as zabbaleen.

Whereas the migrants from Upper Egypt are almost exclusively Coptic Christians, about one in four of the zabbaleen professes the Islamic faith; these include smaller groups of migrants from the Fayum and the southern delta provinces, and also almost all of the inhabitants of the Batn elBakr refuse settlement. A surprising fact here is that the Muslim zabbaleen did not in any way renounce pig-keeping. The astonishing matter of the compatibility of this activity with Islam was explained by reference to the fact that the Prophet had only forbidden the consumption of pig meat, but not the rearing of pigs. 


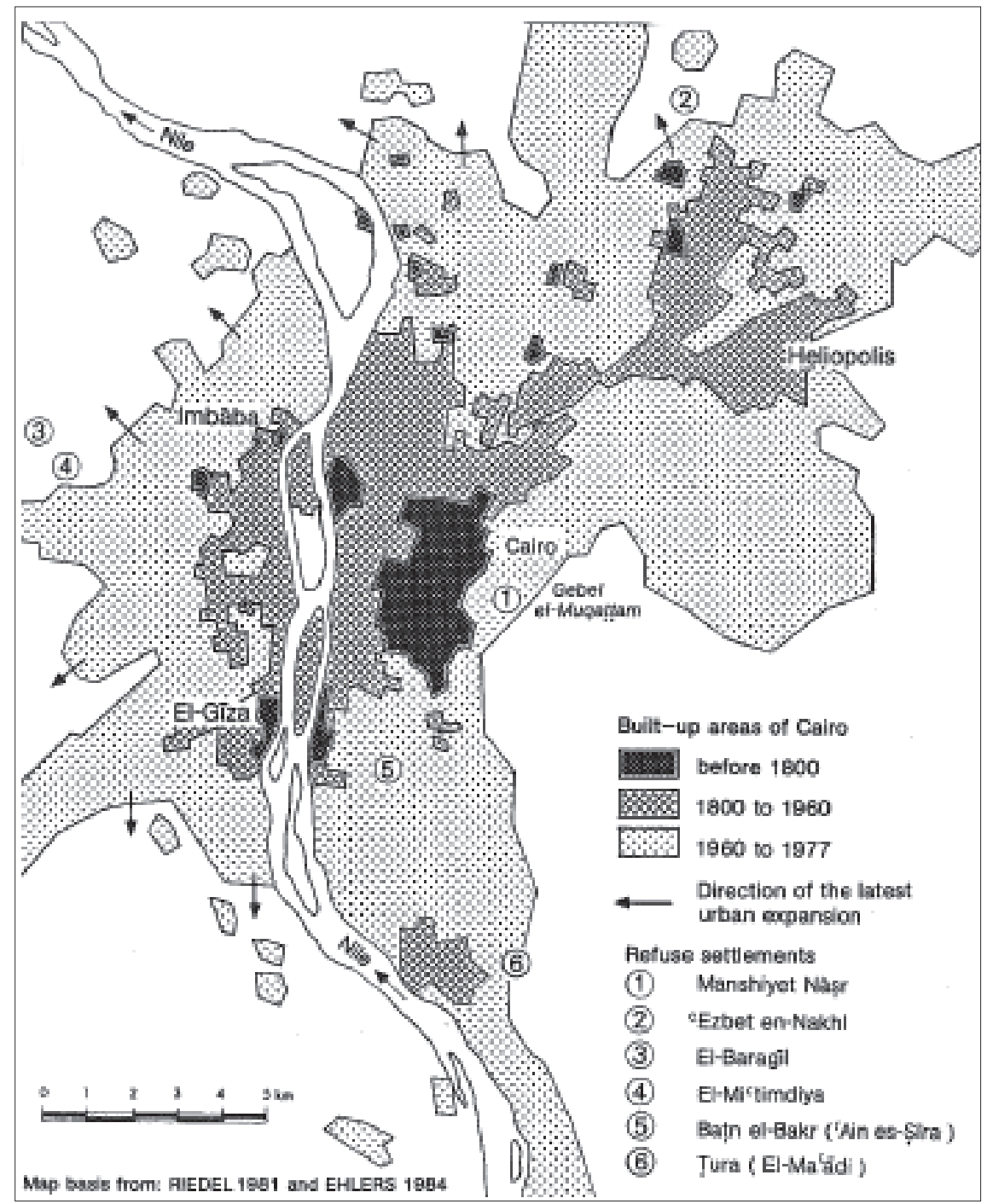

Figure 2: Location of refuse settelements in Greater Cairo

\section{LIVING CONDITIONS IN THE REFUSE-DUMP SETTLEMENTS}

In the past, refuse settlements were established mainly on rented irrigation land and were generally allowed only a brief existence. The zabbaleen had to give way again and again to the town outskirts, expanding all too rapidly. Between 1937 and 1966 - a period in which the population of Cairo shot up from 1.3 to 4.2 million - some of the older refuse collectors had to abandon their settlements up to six times, the last occasion being in September 1970. At that time the inhabitants of the biggest refuse settlement in Imbaba, on the 
north-western outskirts of Cairo, were asked by the authorities to leave the area within a few weeks. A desolate, abandoned stone-quarrying area at the margin of the Muqattam Mountains was offered to them for resettlement. For this unattractive, government-owned desert-land, they were given the assurance that they would never again be expelled from there.

For those refuse collectors whose working-areas were in the urban districts to the west of the Nile, moving to exactly the opposite end of the city was completely out of the question, since they were not allowed to take their donkey carts over the Nile-bridges. They therefore rented irrigated land a few kilometres from the western outskirts of the city and established here the new refuse settlements of El-Baragil and El-Mitimdiya. However, the great majority accepted the government's offer of settlement in the district subsequently named Manshiyet Nasr. For the approximately 400 zabbaleen-families this signified firstly a serious financial loss, since removal with their large herds of pigs across the city and into a desert area was impossible and they therefore had to sell most of their animals at well below their true value within a few days. It was then a matter of carrying out the removal as quickly as possible and without any governmental assistance, establishing a new settlement and, at the same time, continuing to carry out refuse removal. Today, one can only guess at the problems and rigours of the living conditions facing the zabbaleen at the start of their settlement in Manshiyet Nasr, now that the whole infrastructure and public organization have been enormously improved or newly established in the last few years.

Most of the refuse-collecting families in Manshiyet Nasr have in the meantime erected solid accommodations of reinforced concrete, burnt bricks or concrete building blacks, and in a few cases have even begun to add another storey to the buildings. In the other refuse settlements, erected mostly on rented land, almost only huts of corrugated iron are to be found. Here, only very few zabbaleen have managed to raise enough money to buy the land on which their zariba stands - an Arabic word which really means the pen in which pigs are kept, but in everyday language-usage also includes the pigs themselves and the whole farmstead.

The typical ground plan of a refuse-collector's farmstead is given in fig. 3, which shows that the zabbal-families, usually comprising more than 5 people, generally share a living- and bed-room with a floor area of only between 12 and 15 sq.m.

Living in these settlements means constantly being amid dirt, smells, swarms of flies and rats which one can see darting about, even in broad daylight. The hygienic conditions are wretched and infectious diseases of all kinds are almost the norm. Women and small children usually walk and run about in their bare feet, which are often covered in sores and inflamed wounds.

Under such conditions, it is astonishing that not more than one in four of the babies born in the refuse settlements dies before its first year of life is ended (Etribi et al. 1981: 36). 


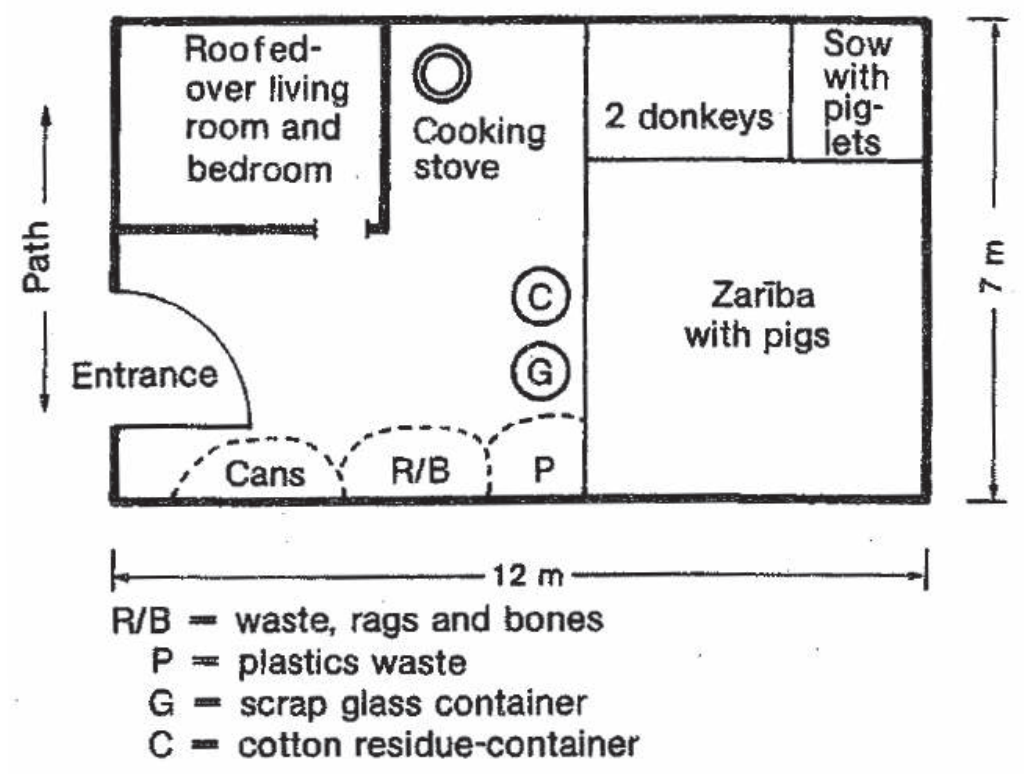

Figure 3: Plan of a typical refuse-collector's farmstead

\section{A DAY IN THE LIFE OF THE ZABBALEEN}

Long before daybreak, the first of the approximately 2000 donkey carts start their often one- to two-hour journey from the refuse settlements to the middle-class and upper-class residential districts of the Egyptian metropolis, in order if possible to reach their working-areas before the morning rush-hour traffic begins (fig. 4). When they arrive there, the small children look after the team of donkeys while their father or older brother starts collecting the refuse from the households. They have before them hours of going up and down stairs - often up to the sixth floor and higher, before they have filled their carts with the refuse from 100 to 250 dwellings.

Late in the morning, most of the teams are on their way home again. Behind, among the high pile of refuse, one can see not infrequently the dirty face of a sleeping child, with mouth and eyes black with flies. The driver sitting at the front nods off again and again, even in the dense road traffic. The donkeys find their own way; but then it becomes critical on steep stretches and unmade roads leading to the refuse settlements, and here the two or three donkeys often can only be persuaded with brutal blows with a stick to continue pulling the heavy cart.

When they finally reach the home farmstead, the single-axle cart is pushed backwards through the entrance gate and tilted back. The evil-smelling load pours through the open tail-gate of the cart and into the inner yard. While some 


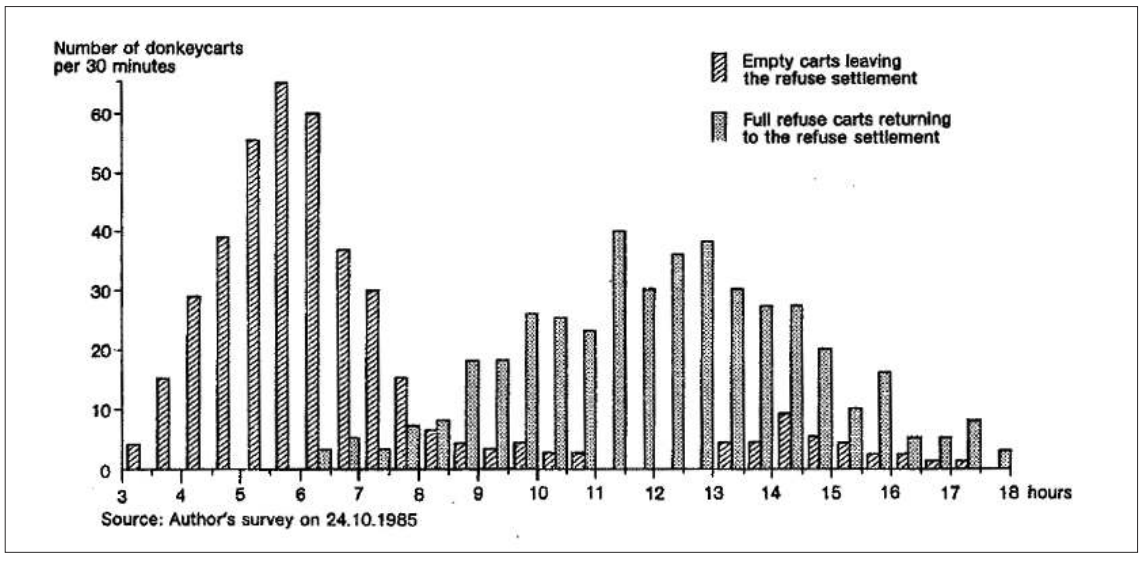

Figure 4: Variation in refuse cart-traffic with the hour of the day, at the main approach road in the refuse settlement of Manshiyet Nasr

of the zaballin set out once more on a second refuse-collecting trip, after a short midday-break, the main work of the older girls and the women begins. They sort the refuse into re-usable scrap materials and organic waste, which is fed to the pigs. Ultimately, only the no longer usable refuse components, such as filth, rusty tin cans and innumerable plastic bags remain. The last-mentioned are burnt on nearby incinerating sites, but also next to the farmstead in some settlements.

When, in the late afternoon, the refuse-fire Hares up on the roads, which are far too narrow, and dense, pungent smoke darkens the sun for hours and makes breathing an agony, being in the settlements becomes almost unbearable. Then, if stronger winds fan the refuse-fire for some days the Hames encroach again and again upon the pitiful huts. The fire is usually put out quickly with the help of neighbours; but there have also been catastrophic fires - as in the year 1976, for example, when a large part of the refuse district at the foot of the Muqattam Mountains fell victim to the Hames.

\section{THE FINANCIAL POSITION OF REFUSE-COLLECTING ENTERPRISES}

The zabbaleen generally earn more than their wretched corrugated iron huts indicate. Thus, the monthly net income of the refuse-collecting enterprises studied generally ranged between 60 and $300 \mathrm{fE}$ at the end of 1985. For Egyptian conditions, where an ordinary civil servant gets a monthly salary of about $60 \mathrm{fE}$, the zabbaleen are thus certainly not among the poorest of the poor; but account must be taken here of the fact that the above enterprise income does not represent the work of one man, but is usually the remuneration of a family consisting of 9.6 persons, on average. Of these, between 2 and 4 adults are working in the enterprise, and the same number of children, aged between 5 and 12 years. 
The zabbaleen's main source of income is pig keeping. Consequently, they do not regard themselves primarily as refuse collectors, but as zarrab i.e. pig breeder. The economic backbone of each of these enterprises is the zariba, in which about 30 pigs and two donkeys can be fed with the organic waste in one cart-load of refuse per day. Such an enterprise is able to sell about $25-35$ pigs a year and thus make between 550 and $800 \mathrm{fE}$. If account is taken also of the fact that in a good half of all zaribas, two or even three carts are used and, with the larger supply of feed, more pigs are reared, it will be seen that the income of the enterprise is doubled or trebled.

However, this does not in any way mean that the incomes mentioned above accrue only to the people who work actively in the zariba. Thus, in more than one-third of all cases the firms are not independent family-enterprises, but enterprises in which the different production factors are owned by investors, who receive part of the operating income in return for their use. Here, the investors are the wealthy members of those occupational groups with whom the refuse collectors deal directly, namely scrap dealers and pig dealers, refuse contractors and other zabbaleen. Three basic forms of participation by investors in the refuse-collecting enterprises can be distinguished here:

- A partnership between the refuse-collecting family and the investor, who accordingly receives a specific percentage share of the operating income for the production factors which he has brought in. If, for example, the investor meets all of the initial capital costs of the enterprise, whereas the zabbal undertakes only the daily jobs of work, then the former will receive three quarters of the proceeds from the sale of the pigs. If the zabbal has a cart and draught animals of his own, and also pays the rent for the land on which the zariba lies, then the investor's share in the pig sales proceeds is reduced to two-thirds. Lastly, if the investments of the two partners are equal, each receives $50 \%$ of the selling price of the pigs. In all three of the above examples, the zabbal also receives all of the income from the sale of scrap materials.

- The investor owns the enterprise and has leased it to a zabbal in return for a fixed monthly sum of 50-60 $\mathrm{eE}$.

- The investor is the owner and head of the enterprise, which is operated for him by paid workers, usually with a zabbal as permanent staff, who with his family does all of the work in the enterprise and receives in return accommodation and monthly pay of 50-60 fE. In some other cases the zabbal receives all of the proceeds from the sale of scrap materials, the wage paid by the owner of the enterprise being then reduced to 25-40 £E a month.

The basic form of participation by investors in refuse-collecting enterprises which was described first was encountered in about one in five zaribas, whereas the other two forms of participation occurred in $9 \%$ of the respective cases studied. In all of the examples described here, the refuse collectors entered into a relationship of close financial dependence with the investor 
concerned, for an unlimited period. In addition, dependent relationships of indebtedness, usually with a time-limit, are frequently encountered, into which the zabbaleen fall by taking up loans. The smallest number of them have sufficient capital of their own for acquiring, for example, a better route from a refuse contractor, or even for financing a complete zariba-enterprise when they start their refuse-collecting - which can cost up to $2000 \mathrm{fE}$. Usually an attempt is first made to borrow from relatives, neighbours and friends the money which is lacking. So it happens, for example, that a zabbal will get together the 350 $£ E$ that is needed to buy a new cart and two donkeys, by taking mini-loans of 5-10 fE each from 20 or more persons. These loans are generally repaid by instalments, without interest.

The picture is different, however, if - as in most cases - the money is borrowed from scrap dealers or pig merchants. Here, repayment is made in each case by the sale of scrap or of pigs through the zabbal. It is customary for the merchant not to charge the usual market price, but a sum which is $10-20 \%$ lower, as debt-repayment.

\section{THE ROLE OF THE PIG MERCHANTS IN THE WASTE-RECYCLING SYSTEM}

One notable exception to the above-mentioned debt-repayment practices is the firm Morcos, by which about one-half of the approximately 50,000 pigs slaughtered annually in Cairo are purchased ${ }^{4}$ and made into pork meat and sausages in its own factory. According to the eldest of the Morcos-brothers, who share the management of the firm, more than 150 zabbaleen have so far received interest-free loans amounting in each case to between 200 and $1000 \mathrm{EE}$, to establish their own zariba. In the same generous manner, the firm also assisted many families who had lost all they had in two big fires in the refuse settlement of Manshiyet Nasr in 1976.

This generosity avoids being totally unselfish only in that the Morcos brothers can be sure that the borrowers will sell their pigs only to themselves and not to the other four merchants by whom the other half of the Cairn pig market is controlled. Instead of squeezing big profits out of the zabbaleen, what matters to the Morcos brothers above all is to have reliable suppliers of pigs who will provide regular supplies for their butchers' shops. Since imports of pig meat into Egypt are prohibited and supplies from the Coptic areas of Upper Egypt stopped at the beginning of the '70s, owing to the lack of animal feeding-stuffs there, the refuse settlements are the only producers of pig meat for the city market. As an extra safeguard against possible bottlenecks in supply,

4 The figures on the number of slaughtered pigs are based upon the records of the Cairo City Slaughter-house for the period from the beginning of October 1984 to the end of September 1985. 
the Morcos firm has its own zaribas with one or two thousand pigs, in one of the refuse settlements. The feed needed for them does not come from domestic waste, however, but from large kitchens and macaroni factories, or is purchased through feeding-stuff merchants.

The pig meat is sold to the consumers not only in the "Royal Charcuterie", which was founded as early as in 1914 by the Morcos brothers' grandfather - a once penniless migrant from a Coptic village south of the Upper Egyptian provincial capital of El-Miniya; today, the family firm has four shops in first class shopping locations. In addition, pig meat is sold in about a dozen other butchers' shops, which are concentrated in the districts of Cairo with a high proportion of Coptic population. After the Copts, the foreigners living in Cairo form the most important group of customers for the pig meat shops.

\section{THE UTILIZATION OF SCRAP MATERIALS}

The refuse collectors get their incomes not only from pig keeping; on average, they get almost one-third from selling scrap materials. The zabbaleen can sort out from one cart-load of refuse, on average, scrap materials with a sales value of between 0.70 and $1.20 \mathrm{fE}$ - depending in each case upon the social class and corresponding consumer behaviour of the households supplying the refuse.

As will be seen from fig. 5, waste plastics and fabrics, paper, cardboard, glass, bones, old footwear, tin cans, aluminium scrap and other scrap metal are included in the recycling. The zabbaleen have only very limited storage facilities and they therefore usually sell scrap materials several times a week, in small portions at the special collecting-establishments which are to be found in the respective refuse settlements. The owners of the collecting-establishments are in some cases themselves zabbaleen who procure for themselves an additional source of income through the retailing of scrap materials. Other collecting depots belong to wholesalers who have several such establishments in the various refuse settlements. Here, the scrap materials are usually sorted only roughly and packed in hales or sacks, whereas further processing is carried out in other districts of Cairo.

In the last few years, however, a change has been taking place in this connection, with more and more zabbaleen starting to undertake the simpler processes of refuse preparation themselves. This applies especially to the large refuse settlement of Manshiyet Nasr (fig. 6), where loans are provided for establishing small enterprises of this kind, by a co-operative which was started by the government. Thus, more than a dozen zabbaleen have been able to acquire machines for granulating plastics waste, plastics injection-moulding machines or a shredder and thus open up their own waste-processing enterprises. Others began with activities requiring less capital, such as leaning plastics scrap, or cutting up tin cans. They were thus able not only to increase their own income, but often also to create new jobs for workers. In the spring of 1986, in the 107 


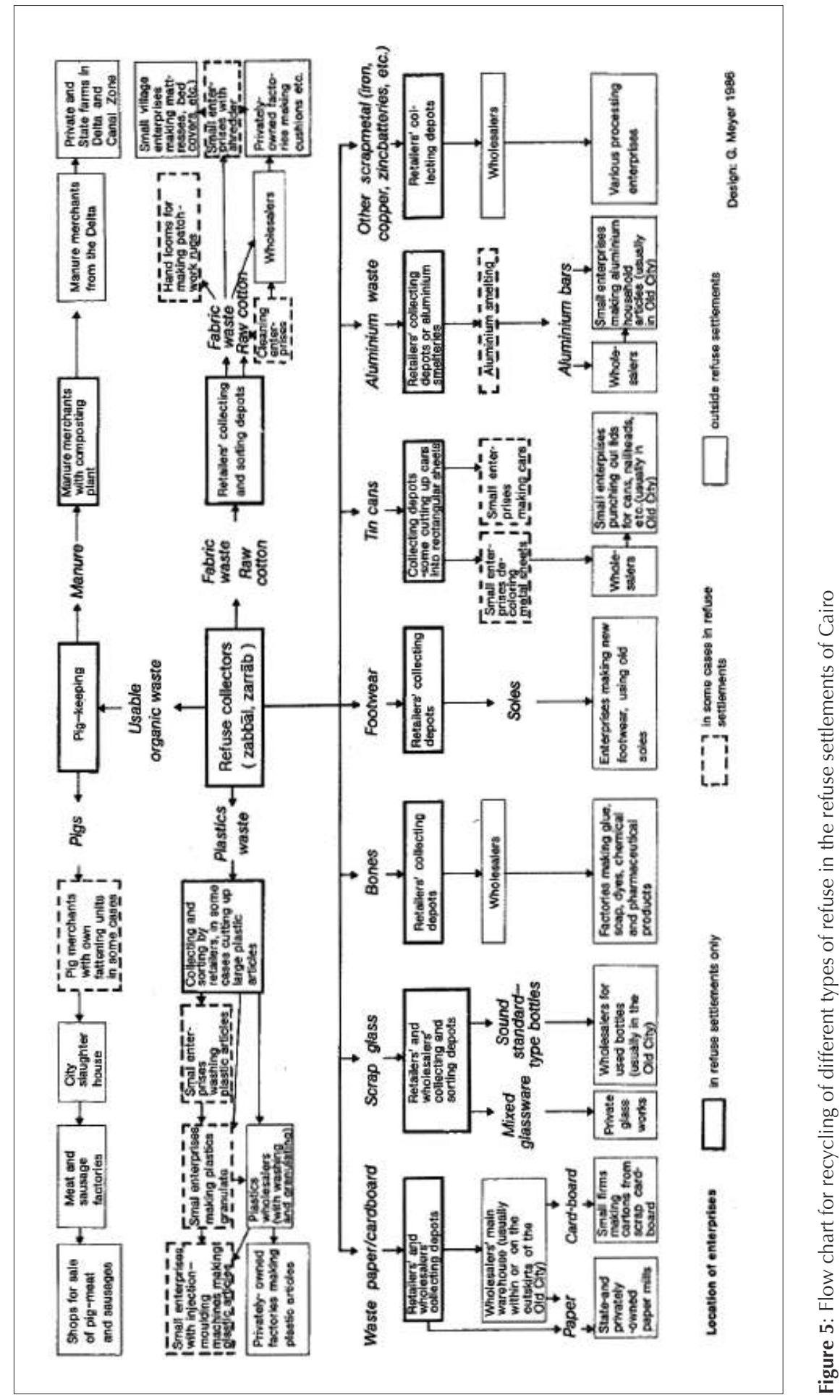




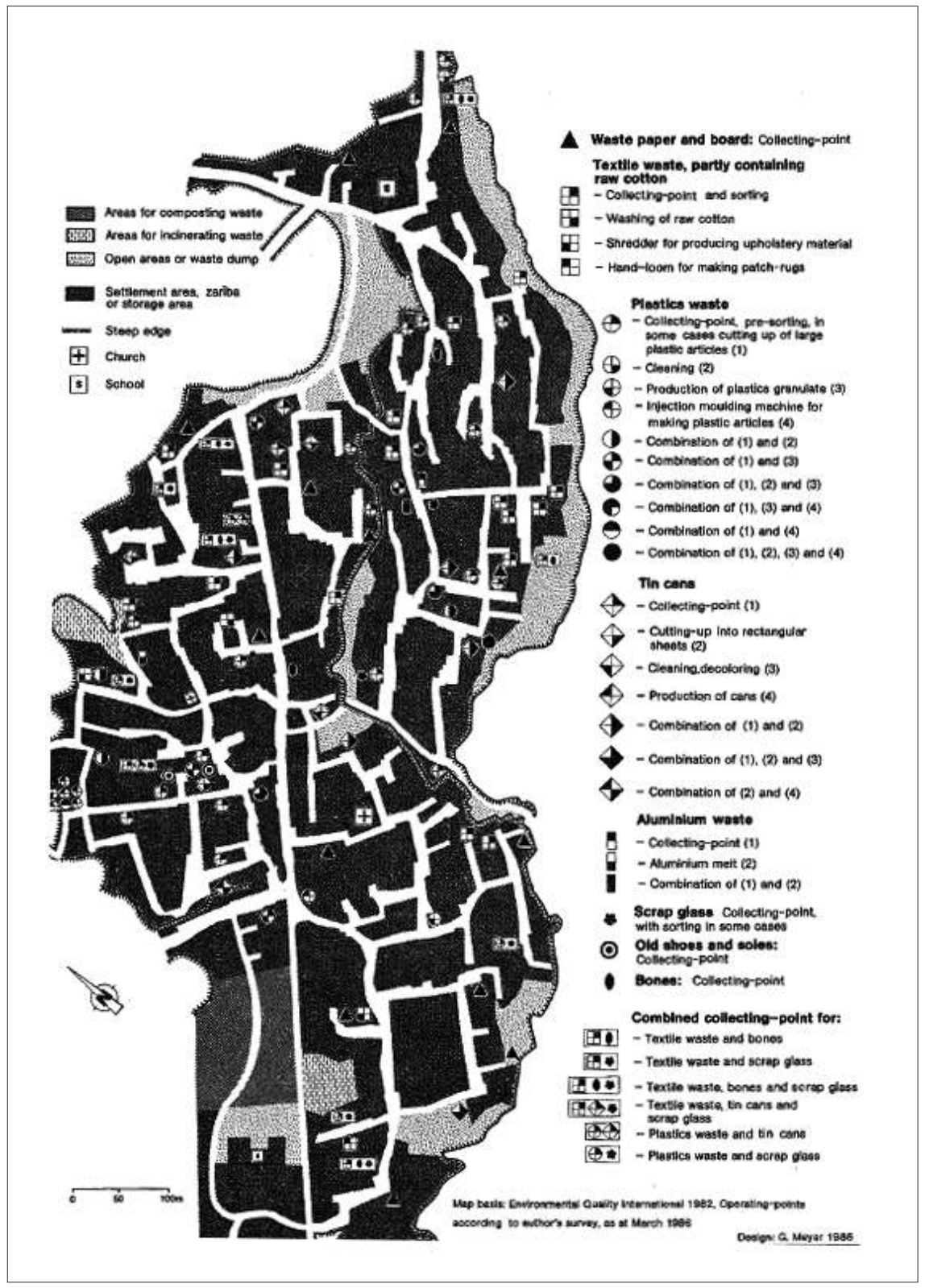

Figure 6: Installations for collection and processing of different kinds of waste in Manshiyet Nasr 
enterprises in which waste materials are collected and partially processed in the refuse settlement of Manshiyet Nasr, for example, more than 200 workers were employed, earning between 1 and $6 \mathrm{fE}$ in daily wages, depending in each case upon the particular type of work clone. Most of them were sons of resident zabbaleen, or had only recently migrated to Cairn from their home villages in Upper Egypt.

The existing system of waste-recycling in Cairo is threatened above all by considerable dangers from the modernistic State planning institutions. It is true that there is acknowledgement of the fact that, if government enterprises were to take over refuse removal from the middle- and upper-class households in Cairo, this would result in fees being four times as high, with falling efficiency, and for this reason there are no plans at all to abolish the zabbaleen. However, their donkey carts have long been a thorn in the side of the government planners, because they not only help to cause the chronic traffic congestion, but are also a blot on the landscape in the modern Egyptian capital.

Even back in 1980, therefore, the zabbaleen were banished into the darkness and any refuse collector who appeared on the streets of Cairo with his cart between sunrise and sunset was threatened with a fine or even confiscation of his vehicle. This hampered the zabbaleen's work so much that the louder and louder complaints from the upper-class households finally resulted in revocation of the decree concerned.

Instead, the planning authorities concentrated upon replacing the "adapted technology" of the donkey carts (cf. Haynes and El-Hakim 1979) with a modern means of transport. For this, there were small Italian tractor vehicles, with a trailer, such as are used by the public cleansing enterprises for refuse removal from the lower-class residential areas. Already at the beginning of 1986, the city centre and representative upper-class districts with a high proportion of foreign residents were to be barred to donkey carts and refuse removal only by the small tractors would continue to be allowed. The reaction to this announcement was nothing but unanimous repudiation and anger: Who would undertake to pay the $6000 \mathrm{fE}$ for every single tractor and the running costs of repair and servicing? Where would the feed for the pigs come from if the tractor is standing for days in the repair shop? How would the low powered tractor cope with the steep slopes and stretches of unmade road? In the trials carried out over a considerable period by the urban cleansing enterprises, it was found, in fact, that the imported tractors were extremely prone to break down and unsuitable for the zabbaleen.

The refuse collectors' donkey carts are thus at present still in operation - but for how long? A more powerful Egyptian-made tractor is to be tried out by the end of 1986 and then put into volume production. A basis of agreement has already been reached in negotiations between the managing board of the refuse contractors' association and the authorities on financing the purchase of the new tractors and on the wahis taking over running costs; in return, the contractors are given the right to make a large increase in the charges for household 
refuse removal. In addition to numerous technical problems, implementation of this scheme would result especially in even more dependence of the zabbaleen upon the contractors.

The refuse collectors are threatened with another danger by the erection of public waste-recycling plants, accelerating even more the fall in prices for scrap materials which has been taking place for years. It would ultimately mean the complete ruin of the zabbaleen if those fundamentalistic religious forces get their way to which pig keeping in an Islamic state has long been a thorn in the flesh. With a ban on pig keeping, the existing waste-recycling system in Cairo would lose its economic basis and this would destroy the livelihood of more than 20,000 people.

\section{BIBLIOGRAPHIE}

Baer G., 1964, Egyptian guilds in modern times, Jerusalem, The Israel Oriental Society.

Ehlers E., 1984, "Àgypten. Zur Urbanisierung einer agraren Gesellschaft », Geographische Rundschau, vol. 36, p. 220-229.

Elwert G., Evers H. D., Wilkens W., 1983, " Die Suche nach Sicherheit: Kombinierte Produktionsformen im sogenannten informellen Sektor », Zeitschrift für Soziologie, vol. 12, nº 4, p. 281-296.

Etribi T., Oldham L., Neamatalla M., 1981, The people of the Gabbal: Life and work among the Zabbaleen of Manshiyet Nasser, Reportn ${ }^{\circ} 3$, Cairo, Environmental Quality International.

Haynes K. E., El-Hakim S., 1979, "Appropriate technology and public policy: The urban waste management system m Cairo », Geographical Review, vol. 19, nº 1, p. 101-108.

Herrle P., 1983, « Der informelle Sektor. Die Ôkonomie des Überlebens in den Metropolen der Dritten Welt », Stadtprobleme in der Dritten Welt. Materialien zum Internationalen Kulturaustausch, Vol. 18, p. 47-62.

Meyer G., 1980, " Die Zuwanderung aus den agyptischen Oasen nach Kairo », Der Islam, vol. $57, \mathrm{n}^{\circ} 1$, p. 36-50.

Riedel S., 1982, "Wohnungsbau" für die untersten Einkommensschichten in Agypten », Stadtbauwelt, vol. 72, n 70, p. 162-165.

Sanitary Commissioner of Cairo, 1909a, "The cleansing of Cairo », The Lancet, vol. 173, $n^{\circ} 4476$, p.1720-1723.

Sanitary Commissioner of Cairo, 1909b, "The cleansing of Cairo (2) », The Lancet, vol. 173, $\mathrm{n}^{\circ} 4477$, p. 17821784 .

Sethuraman S. V., 1976, "The urban informal sector: concept, measurement and policy ", International Labour Review, vol. 114, no 1, p. 69-81.

Sethuraman S. V., (dir.), 1981, The urban informal sector in developing countries, Genf, International Labour Office. 